\title{
Right-to-left shunt determination in dog lungs under inhalation anesthesia with rebreathing and non-rebreathing system ${ }^{1}$
}

\author{
Determinação de shunt venoso-arterial em pulmões de cães sob anestesia geral \\ inalatória por sistemas com e sem reinalação
}

\author{
André Leguthe Rosa², Patrícia Cristina Azevedo Mota ${ }^{3}$, Yara Marcondes Machado Castiglia ${ }^{4}$ \\ 1. Research performed from Experimental Laboratory of Department of Anesthesiology, School of Medicine, State University of São \\ Paulo (UNESP). Botucatu, Brazil. \\ 2. PhD, São Paulo Methodistic University, School of Veterinary Medicine. São Bernardo do Campo, Brazil. \\ 3. Veterinary anesthesiologist. \\ 4. Full Professor, Department of Anesthesiology of UNESP. Botucatu, Brazil.
}

\begin{abstract}
Purpose: To investigatge right-to-left shunt determination in dog lungs under inhalantion anesthesia with non-rebreathing and rebreathing systems and fraction of inspired oxygen $\left(\mathrm{F}_{\mathrm{I}} \mathrm{O}_{2}\right)$ of 0.9 and 0.4 , respectively. Methods: Two groups of 10 dogs each under inhalation anesthesia with sevoflurane: GI in which it was utilized non-rebreathing semiclosed system and $\mathrm{F}_{\mathrm{I}} \mathrm{O}_{2}=0.9$, and $\mathrm{GII}$ in which it was utilized rebreathing semiclosed system and $\mathrm{F}_{\mathrm{I}} \mathrm{O}_{2}=0.4$. The study parameters were: heart rate, medium arterial pressure, right-to-left intrapulmonary shunt, hematocrit, hemoglobin, arterial partial pressure of oxygen, mixed venous partial pressure of oxygen, mixed venous oxygen saturation, arterial partial pressure of carbon dioxide, partial pressure of water in the alveoli. Results: Shunt results were significantly different between the two groups - GI data were higher than GII in all the evaluated moments. Hence, the group with nonrebreathing (GI) developed a superior grade of intrapulmonary shunt when compared with the rebreathing group (GII). The partial pressure of water in the alveoli was significantly higher in GII. Conclusion: The inhalation anesthesia with non-rebreathing system and $\mathrm{F}_{\mathrm{I}} \mathrm{O}_{2}=$ 0.9 developed a higher grade of intrapulmonary right-to-left shunt when compared with the rebreathing system and $\mathrm{F}_{\mathrm{I}} \mathrm{O}_{2}$ $=0.4$. The higher humidity in GII contributed to the result.
\end{abstract}

Key words: Anesthesia, Inhalation. Anesthesia, Closed-Circuit. Atelectasis. Dogs.

\section{RESUMO}

Objetivo: Comparar a formação de shunt venoso-arterial em pulmões de cães submetidos a anestesia geral inalatória utilizando-se sistemas de anestesia com e sem reinalação, com fração inspirada de oxigênio de 0,4 e 0,9, respectivamente. Métodos: Empregaram-se 20 cães induzidos com tiopental sódico (30mg/kg) e mantidos com sevoflurano (3\%) e alocados em dois grupos $(\mathrm{n}=10)$; os animais de GI foram ventilados com modalidade controlada em sistema semifechado, sem reinalação, $\mathrm{F}_{\mathrm{I}} \mathrm{O}_{2}=0,9$, e os de GII, com modalidade controlada, sistema semifechado, com reinalação e $\mathrm{F}_{\mathrm{I}} \mathrm{O}_{2}=0,4$. Os atributos analisados durante o experimento foram: freqüência cardíaca, pressão arterial média, shunt pulmonar venosoarterial, hematócrito, hemoglobina, pressão parcial de oxigênio arterial, pressão parcial de oxigênio no sangue venoso misto, saturação de oxigênio no sangue venoso misto, pressão parcial de dióxido de carbono arterial e pressão de vapor de água nos alvéolos $\left(\mathrm{P}_{\mathrm{VA}}\right)$. Resultados: $\mathrm{A} \mathrm{P}_{\mathrm{VA}}$ foi significativamente maior em GII. A análise estatística dos valores encontrados de shunt mostrou que GI e GII apresentaram diferenças significativas, sendo que os resultados de GI são maiores que os de GII em todos os momentos avaliados. Já a análise de momentos dentro de um mesmo grupo não demonstrou diferenças. Conclusão: $\mathrm{O}$ sistema de anestesia sem reinalação com $\mathrm{F}_{\mathrm{I}} \mathrm{O}_{2}=0,9$ desenvolveu maior grau de shunt pulmonar venoso-arterial que o sistema de anestesia com reinalação e $\mathrm{F}_{\mathrm{I}} \mathrm{O}_{2}=0,4$. A umidificação dos gases em GII contribuiu para diminuir o shunt.

Descritores: Anestesia por Inalação. Anestesia com Circuito Fechado. Atelectasia. Cães.

\section{Introduction}

In inhalation or intravenous general anesthesia with mechanical ventilation ${ }^{1}$, gases exchanges mishaps occur due to pulmonary atelectasis ${ }^{2,3}$, resulting in blood oxygenation decrease. ${ }^{4}$ This phenomenon is observed few minutes after induction of anesthesia in $85 \%$ to $90 \%$ of patients $^{5}$, being the higher grade in those with morbid obesity or when there is high oxygen fraction inspired $\left(\mathrm{F}_{\mathrm{I}} \mathrm{O}_{2}\right) .{ }^{2,6}$ Atelectasis is found in different grades according to lung area, and also with a correlation between present shunt grade and the amount of atelectasis developed ${ }^{7}$, which results in a poor gases exchange. ${ }^{8}$ In regions close to diaphragm, atelectasis ranges from $20 \%$ to $25 \%$. Those 
patients will display sanguineous right to left shunt and arterial oxygen partial pressure $\left(\mathrm{P}_{\mathrm{a}} \mathrm{O}_{2}\right)$ will be much lower than oxygen alveolar pressure $\left(\mathrm{P}_{\mathrm{A}} \mathrm{O}_{2}\right)$. Under these circumstances, $100 \%$ concentration of oxygen inhalation does not raise $\mathrm{P}_{\mathrm{a}} \mathrm{O}_{2}$ to the expected level. Mechanical ventilation used in general anesthesia procedures causes changes in the relationship between ventilation and perfusion (ventilation/perfusion ratio) favoring the development of hypoxemia, because some pulmonary units remain hypoventilated in relation to their blood flow. However, the inhalation of $100 \%$ oxygen eliminates the inertial gas (nitrogen). The alveoli with lower ventilation become more oxygenated as well as the blood that flows through them. So, it is easy to differentiate the shunt from changes in pulmonary ventilation/perfusion ratio in the patient that inhales only oxygen. The use of lower $\mathrm{F}_{\mathrm{I}} \mathrm{O}_{2}$ prevents the early formation of atelectasis, contrarily to what happens when $\mathrm{F}_{\mathrm{I}} \mathrm{O}_{2}=1.0$ is used. During anesthesia procedure, when $\mathrm{F}_{\mathrm{I}} \mathrm{O}_{2}$ is raised from 0.21 to 0.50 , there are changes in the difference between $\mathrm{P}_{\mathrm{A}} \mathrm{O}_{2}$ and $\mathrm{P}_{\mathrm{a}} \mathrm{O}_{2}$ but not in the ventilation/perfusion ratio. ${ }^{10}$ However, the rise in $\mathrm{F}_{\mathrm{I}} \mathrm{O}_{2}$ is related to the rise in the shunt occurrence. Study ${ }^{11}$ carried out in patients under $\mathrm{F}_{\mathrm{I}} \mathrm{O}_{2}$ of $1.0,0.8$, and 0.6 showed that with $\mathrm{F}_{\mathrm{I}} \mathrm{O}_{2}=1.0$ patients had higher levels of atelectasis and thus higher grade of pulmonary shunt. Physiologically, the superior portion of the respiratory tract heats and moistens the inhaled gases. Nevertheless, in mechanical ventilation dry and cold gases have an intimate contact with trachea and the whole respiratory tree determining some changes, as microatelectasis, inadequacy in ventilation/perfusion ratio and in ciliary movement, higher respiratory resistance, decrease in pulmonary compliance as well as in functional residual capacity. ${ }^{12}$ During anesthesia there is the possibility of using expired gases, redirecting them to the circular filter system that works then as a gas conductor, reservoir and carbon dioxide absorber. As a result, the fresh air flow is lowered as well as the $\mathrm{F}_{\mathrm{I}} \mathrm{O}_{2}$ and there is some warming and humidification of the inhaled gases by the chemical reaction that neutralizes carbon dioxide, resulting in heat and water, thus possibly reducing atelectasis. ${ }^{12,13}$ So, the aim of this research was to investigate, in dog lungs under inhalation anesthesia procedure and mechanical ventilation, the shunt formation in a non-rebreathing anesthesia system with a $\mathrm{F}_{\mathrm{I}} \mathrm{O}_{2}$ of 0.9 and in a rebreathing anesthesia system with a $\mathrm{F}_{\mathrm{I}} \mathrm{O}_{2}$ of 0.4 .

\section{Methods}

Twenty three male and female crossbred adult dogs, body weight ranging from 14 to $23 \mathrm{~kg}$, were used. Animals were provided by the Central Laboratory of the São Paulo State University, Botucatu Campus, with the approval of Ethics Committee in Animal Experimentation. Three out of 23 dogs were chosen to standardize the techniques used in this study and 20 were divided into 2 groups (10 animals each). Animals were given sodium thiopental, a $30 \mathrm{mg} . \mathrm{kg}^{-1}$ dose, for the induction, and sevoflurane at $3 \%$, for maintenance. Dialil-bis-nortoxiferina, $0.02 \mathrm{mg} . \mathrm{kg}^{-1} \mathrm{dose}$, was utilized as a muscular relaxant. After orotracheal intubation the animal was conducted to an anesthesia device Takaoka 2600 (Brazil), Nikkei Series, with Takaoka Ventilator (674 model) and to the analyzer gas system Datex Engstrom (Finland) $\left(\mathrm{F}_{\mathrm{I}} \mathrm{O}_{2}\right.$, end tidal carbon dioxide pressure and inhaled anesthetic concentration performed through gas sampling collected by tracheal tube). Then, controlled ventilation was established with a tidal volume of $15 \mathrm{~mL}$. $\mathrm{kg}^{-1}$ and a breath rate of 12 to 16 movements per minute. The animals were given $\mathrm{F}_{\mathrm{I}} \mathrm{O}_{2}$ of 0.9 or 0.4 according to the group which they belonged to, GI or GII, respectively. The oxygen fractions were controlled through oxygen mixed with air in the rotameter of the anesthetic device, representing the fresh gas flow. The fresh gas flow provided in GI composed the minute volume enough to supply the respiratory minute volume of the animal and, in GI, the gas fresh flow volume ranged from $800 \mathrm{~mL}$ to $1000 \mathrm{~mL}$. $\mathrm{min}^{-1}$. Anesthesia was maintained with $3 \%$ sevoflurane in both groups studied. Hemoglobin saturation was measured with a sensor placed in the animal's tongue and connected to the Datex Engstrom monitor. Dissection and catheterization of the left femoral artery and vein and right femoral vein were performed - the left femoral vein for lactated Ringer infusion $\left(0.4 \mathrm{~mL} \cdot \mathrm{kg}^{-1} \cdot \mathrm{min}^{-1}\right)$ and the neuromuscular blocking drug, the left femoral artery for measuring the mean arterial pressure as it was connected to the Datex Engstrom monitor and for collecting blood samples for gasometry, and the right femoral vein for blood samples for hematocrit and hemoglobin determination. After scrubbing the proper area, the dissection of the external jugular vein was undertaken and a vein dilatator was placed in order to set a Swan-Ganz catheter. This catheter was allocated in the pulmonary artery with visualization through a Datex Engstrom device, providing the means to collect venous mixed blood. Electrodes were placed on the animal's thorax for electrocardiogram follow up. Lead DII was employed through which rhythm and heart rate were monitored. During all experiment, esophagus temperature was measured by a thermometer placed in a probe localized in the esophagus and analyzed by the Datex Engstrom monitor. Ambient temperature was measured by a thermometer placed at the animal's side. For normal temperature maintenance the room had air conditioning. The groups were differentiated by two anesthesia system types and two different $\mathrm{F}_{\mathrm{I}} \mathrm{O}_{2}$. In group I (GI) individuals were kept with control mode in semiclosed non- rebreathing system with $\mathrm{F}_{\mathrm{I}} \mathrm{O}_{2}=0.9$ in air. In group II (GII) animals were kept under control mode in semiclosed rebreathing system with $\mathrm{F}_{\mathrm{I}} \mathrm{O}_{2}=0.4$ in air. In order to perform shunt calculation, attributes evaluated were hemodynamics (heart rate, mean arterial pressure and rightto-left shunt, haematocrit, hemoglobin, arterial oxygen partial pressure, mixed venous blood oxygen partial pressure, saturation of oxygen in the mixed venous blood, arterial carbon dioxide partial pressure) and water vapor pressure in the inhaled gas. All variable measurements were effectuated before the onset of the experiment: M1 (immediately after the preparation of the experimental model), M2 (5 minutes after M1), M3 (10 minutes after M1), M4 (20 minutes after M1), M5 (30 minutes after M1), M6 (40 minutes after M1). It was utilized Stat Profile Plus 5 device (USA) for arterial and mixed venous blood reading, with samples collected in syringes with heparin. The water vapor pressure of the inspired gas measurement (in $\mathrm{mmHg}$ ) was obtained through a hygrometer Gulton (Brazil) model 95. For this 
measurement the device was connected to the tracheal canulla and to the inspiratory ventilation system. The following formula was utilized.

$$
\text { Water vapor pressure }=\frac{\mathrm{RU}_{\mathrm{x}} \mathrm{P}_{\mathrm{wT}}}{100} \text { where }
$$

$\mathrm{RU}=$ relative humidity $(\%) ; \mathrm{P}_{\mathrm{WT}}=$ water vapor pressure $(\mathrm{mmHg})$ according to temperature $\left(\mathrm{C}^{\circ}\right)$ obtained in table that relates both, when there is maximum water content. For shunt determination the following formula was used.

$$
\frac{\mathrm{Qs}}{\mathrm{Qt}}=\frac{\left(\mathrm{P}_{\mathrm{A}} \mathrm{O}_{2}-\mathrm{P}_{\mathrm{a}} \mathrm{O}_{2}\right) \times 0.0031}{\mathrm{a}-\mathrm{vDO}_{2}+\left(\mathrm{P}_{\mathrm{A}} \mathrm{O}_{2}-\mathrm{P}_{\mathrm{a}} \mathrm{O}_{2}\right) \times 0.0031} \text { where }
$$

$\mathrm{Qs}=$ blood flow in non-ventilated capillary $\left(\mathrm{mL} \cdot \mathrm{min}^{-1}\right)$.

$\mathrm{Qt}=$ pulmonary blood flow $\left(\mathrm{mL} \cdot \mathrm{min}^{-1}\right) ; \mathrm{P}_{\mathrm{A}} \mathrm{O}_{2}=$ alveolar oxygen partial pressure $(\mathrm{mmHg}) ; \mathrm{P}_{\mathrm{a}} \mathrm{O}_{2}=$ arterial oxygen partial pressure; $0.0031=$ Bunsen solubility coefficient for plasma soluble $\mathrm{O}_{2}$; a-vDO $=$ arterial-venous oxygen difference (vol \%)

For $\mathrm{P}_{\mathrm{a}} \mathrm{O}_{2}$.

$$
\mathrm{P}_{\mathrm{a}} \mathrm{O}_{2}=\mathrm{P}_{\mathrm{I}} \mathrm{O}_{2}-\mathrm{P}_{\mathrm{a}} \mathrm{Co}_{2}\left(\mathrm{~F}_{\mathrm{I}} \mathrm{O}_{2}+\frac{1-\mathrm{F}_{\mathrm{I}} \mathrm{O}_{2}}{\mathrm{R}}\right) \text { where }
$$

$\mathrm{P}_{\mathrm{I}} \mathrm{O}_{2}=$ inhaled $\mathrm{O}_{2}$ pressure equal to $\left(\mathrm{P}_{\mathrm{b}}-\mathrm{P}_{\mathrm{wV}}\right) \mathrm{F}_{\mathrm{I}} \mathrm{O}_{2}$, being $\mathrm{P}_{\mathrm{b}}$ the local barometric pressure and $\mathrm{P}_{\mathrm{WV}}$, the water vapor pressure of the relative humidity read by the hygrometer with its correspondent temperature (pressure in $\mathrm{mmHg}$ ); $\mathrm{F}_{\mathrm{I}} \mathrm{O}_{2}=$ inspired $\mathrm{O}_{2}$ fraction; $\mathrm{P}_{\mathrm{A}} \mathrm{CO}_{2}=\mathrm{CO}_{2}$ partial pressure in the alveoli (considered the same as $\mathrm{P}_{\mathrm{a}} \mathrm{CO}_{2}$, arterial $\mathrm{CO}_{2}$ partial pressure); $\mathrm{R}=$ respiratory coefficient (as we worked with healthy dogs, $\mathrm{R}$ was assumed to be equal to 0.8 ).

For arterial-venous difference.

$$
\begin{aligned}
& \mathrm{a}-\bar{v} \mathrm{DO}_{2}=\mathrm{C}_{\mathrm{a}} \mathrm{O}_{2}-\mathrm{CvO}_{2} \\
& \mathrm{C}_{\mathrm{a}} \mathrm{O}_{2}=(\mathrm{Hb} \times 1.39) \mathrm{S}_{\mathrm{a}} \mathrm{O}_{2}+\left(\mathrm{P}_{\mathrm{a}} \mathrm{O}_{2} \times 0.0031\right) \\
& \mathrm{C}_{\mathrm{v}} \mathrm{O}_{2}=(\mathrm{Hb} \times 1.39) \mathrm{S}_{\mathrm{v}} \mathrm{O}_{2}+\left(\mathrm{P}_{\mathrm{v}} \mathrm{O}_{2} \times 0.0031\right)
\end{aligned}
$$

where

$\mathrm{C}_{\mathrm{a}} \mathrm{O}_{2}=\mathrm{O}_{2}$ concentration in the arterial blood (vol\%);
$\mathrm{C}_{\overline{\mathrm{v}}} \mathrm{O}_{2}=\mathrm{O}_{2}$ concentration in the mixed venous blood (vol \%); $\mathrm{Hb}=$ hemoglobin concentration $\left(\mathrm{g} . \mathrm{dL}^{-1}\right) ; 1.39=\mathrm{mL}$ of $\mathrm{O}_{2}$ transported by $1 \mathrm{~g}$ of $\mathrm{Hb} ; \mathrm{S}_{\mathrm{a}} \mathrm{O}_{2}=$ arterial blood $\mathrm{Hb}$ saturation; $\mathrm{S}_{\bar{v}} \mathrm{O}_{2}=$ mixed venous blood $\mathrm{Hb}$ saturation; $\mathrm{P}_{\bar{v}} \mathrm{O}_{2}=$ mixed venous $\mathrm{O}_{2}$ partial pressure.

\section{Statistical analysis}

The profile analysis was employed for each variable with hypothesis $\mathrm{Ho}_{1}$ : interaction between the groups and moment - both groups profile can be considered similar; $\mathrm{Ho}_{2}$ : difference between the profiles - groups are evaluated, in case they are similar they differ among them in the 6 moment set; $\mathrm{Ho}_{3}$ : moment difference - in case profiles are taken as similar it was verified whether or not there was difference between groups, at a given moment, separately; $\mathrm{Ho}_{5}$ : difference among moments within each group, separately. For statistics, values were considered significant when $\mathrm{p}<0.05$ and $\mathrm{p}$ is the significance level associated to calculated statistics. When $0.05<\mathrm{p}<0.10$, tendency was referred. Group means contrasts were verified calculating the minimum significant difference, $\alpha=0.05$, by Tukey test.

\section{Results}

Heart rate has lowered in a significant fashion through time in GI and from M1 to M2 in GII, and mean arterial pressure did not develop any significant change, although hematocrit and hemoglobin lowered by the experiment end, but with no clinical significance (Table 1). The $\mathrm{P}_{\mathrm{a}} \mathrm{O}_{2}$ of GI showed values significantly higher $(\mathrm{p}<0.001)$ than that of GII (Table 1), as in mixed venous blood, $\mathrm{P}_{\mathrm{v}} \mathrm{O}_{2}$ and $\mathrm{S}_{\mathrm{v}} \mathrm{O}_{2}(\mathrm{p}<$ 0.05 ) (Table 2), but during the experiment the values displayed no statistical or biological change. The water vapor pressure showed values remarkably higher $(\mathrm{p}<0.05)$ in GII in all evaluated moments (Table 2 and Figure 1). M3 was the higher value observed in GI and M5 in GII. As far as arterial carbon dioxide partial pressure is concerned, GI showed a tendency $(0.05<\mathrm{p}<0.10)$ to higher values than GII. In GI there were changes among moments and in M5 it was observed the higher value (Table 2). Right-to-left shunt increased significantly in GI and this group was greater than GII, which showed normal values $(\mathrm{p}<0.001)$. The analysis of moments in the same group resulted into no difference (Figure 2).

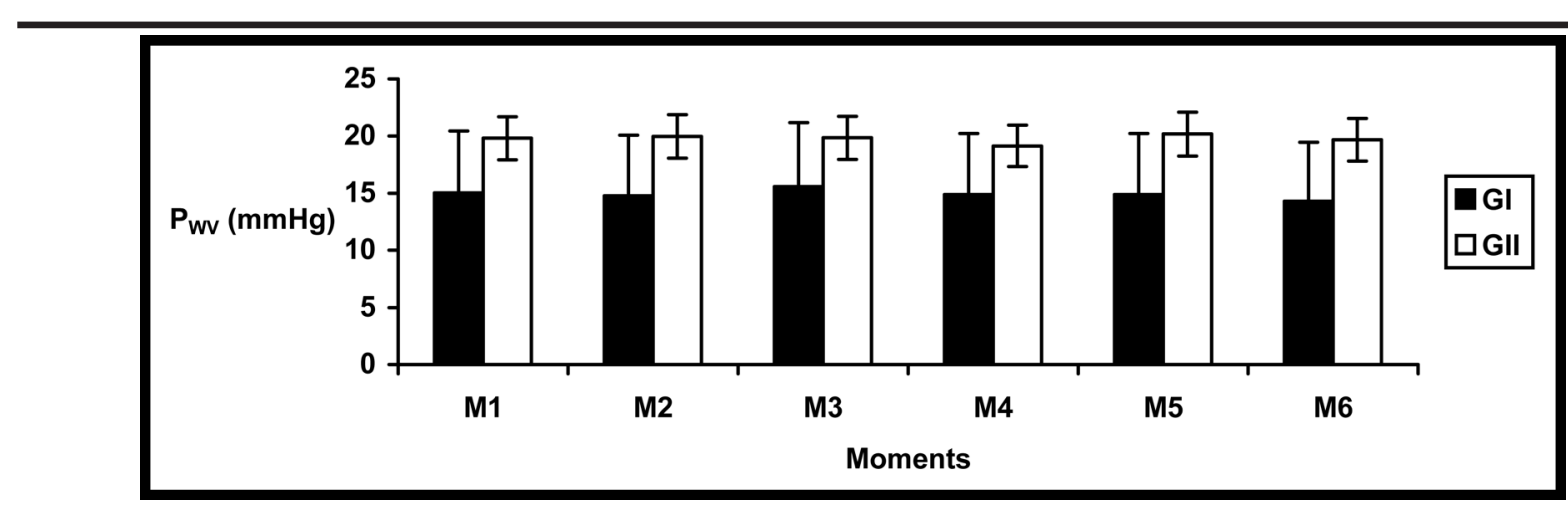

FIGURE 1 - Water vapor pressure (mmHg) (PWV). Mean and standard deviation of observed values in each moment in both experimental groups 
TABLE 1 - Mean and standard deviation of observed values in each moment in both experimental groups

\begin{tabular}{cclcccc}
\hline Groups & Moments & $\mathrm{HR}(\mathrm{bpm})$ & $\mathrm{MAP}(\mathrm{mmHg})$ & $\mathrm{Ht}(\%)$ & $\mathrm{Hb}(\mathrm{g} / \mathrm{dL})$ & $\mathrm{P}_{\mathrm{a}} \mathrm{O}_{2}{ }^{\&}(\mathrm{mmHg})$ \\
\hline \multirow{3}{*}{ GI } & M1 & $146 \pm 18$ & $118 \pm 18$ & $31.5 \pm 4.0$ & $11.7 \pm 2.1$ & $389 \pm 57$ \\
& M2 & $140^{*} \pm 15$ & $113 \pm 16$ & $31.8 \pm 3.2$ & $12.2 \pm 2.7$ & $390 \pm 53$ \\
& M3 & $138^{*} \pm 15$ & $113 \pm 16$ & $31.3 \pm 2.8$ & $11.6 \pm 1.9$ & $394 \pm 47$ \\
& M4 & $134^{*} \pm 15$ & $116 \pm 15$ & $30.6 \pm 4.3$ & $12.4 \pm 2.6$ & $394 \pm 57$ \\
& M5 & $129^{*} \pm 17$ & $113 \pm 12$ & $30.0 \pm 2.7$ & $11.5 \pm 2.2$ & $381 \pm 64$ \\
& M6 & $126^{*} \pm 14$ & $115 \pm 13$ & $30.4 \pm 2.6$ & $11.3 \pm 1.8$ & $402 \pm 53$ \\
\hline \multirow{6}{*}{ GII } & M1 & $155 \pm 23$ & $100 \pm 26$ & $32.8 \pm 6.7$ & $12.1 \pm 3.5$ & $199 \pm 42$ \\
& M2 & $149^{*} \pm 23$ & $102 \pm 29$ & $32.0 \pm 5.2$ & $11.4 \pm 2.6$ & $197 \pm 34$ \\
& M3 & $149 \pm 24$ & $103 \pm 28$ & $31.2 \pm 4.8$ & $10.0 \pm 2.2$ & $196 \pm 32$ \\
& M4 & $144 \pm 26$ & $103 \pm 27$ & $30.8 \pm 5.6$ & $10.8 \pm 2.4$ & $199 \pm 20$ \\
& M5 & $146 \pm 25$ & $101 \pm 28$ & $31.1 \pm 4.8$ & $11.0 \pm 2.7$ & $208 \pm 30$ \\
\hline
\end{tabular}

$\mathrm{HR}$ - heart rate; MAP - mean arterial pressure; $\mathrm{Ht}$ - hematocrit; $\mathrm{Hb}$ - hemoglobin; $\mathrm{P}_{\mathrm{a}} \mathrm{O}_{2}$ - arterial oxygen partial pressure; * $\mathrm{p}<0.05$ versus $\left.\mathrm{M} 1 ;{ }^{\&} \mathrm{p}<0.001\right)$ and $\mathrm{GI}>\mathrm{GII}$.

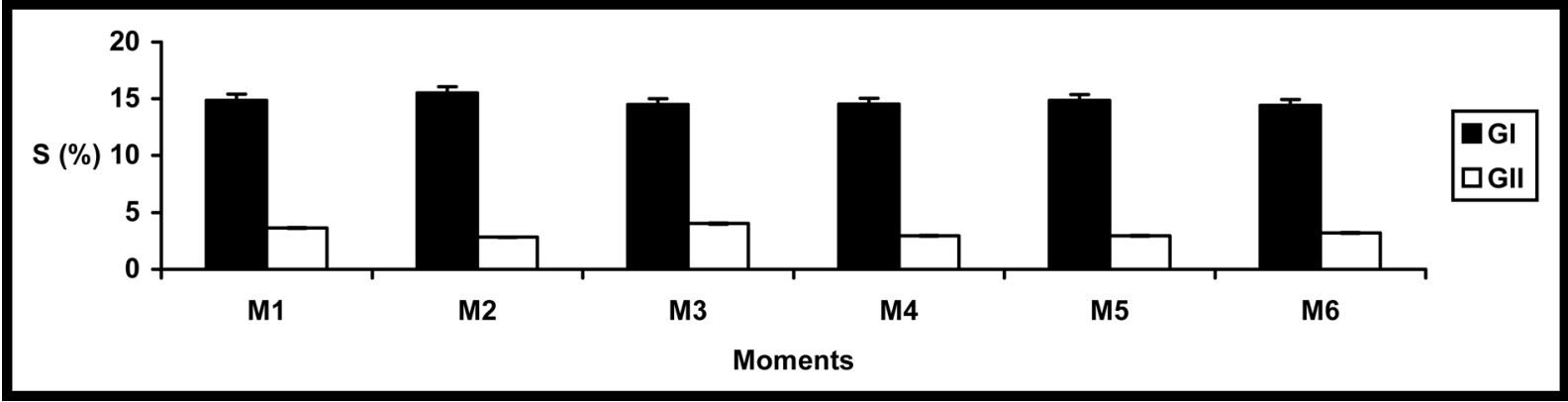

FIGURE 2 - Right-to-left Shunt (\%) (S). Mean and standard deviation of observed values in each moment in both experimental groups

TABLE 2 - Mean and standard deviation of observed values in each moment in both experimental groups

\begin{tabular}{|c|c|c|c|c|c|c|}
\hline Groups & Moments & $\mathrm{S}_{(\%)}$ & $\mathrm{P}_{\mathrm{WV}}{ }^{\#}(\mathrm{mmHg})$ & $\mathrm{P}_{\mathrm{v}} \mathrm{O}_{2}^{\cdot}{ }_{(\mathrm{mmHg})}$ & $\mathrm{S}_{\mathrm{v}} \mathrm{O}_{2} \cdot(\%)$ & $\mathrm{P}_{\mathrm{a}} \mathrm{CO}_{2}^{\mathfrak{E}}(\mathrm{mmHg})$ \\
\hline \multirow{6}{*}{ GI } & M1 & $14.9 \pm 5.3$ & $15.0 \pm 4.5$ & $55 \pm 8$ & $84 \pm 5$ & $35 \pm 9$ \\
\hline & M2 & $15.5 \pm 5.3$ & $14.8 \pm 5.8$ & $58 \pm 8$ & $85 \pm 4$ & $35 \pm 10$ \\
\hline & M3 & $14.5 \pm 4.8$ & $15.6^{*} \pm 6.3$ & $56 \pm 9$ & $86 \pm 5$ & $36 \pm 8$ \\
\hline & M4 & $14.5 \pm 5.7$ & $14.9 \pm 5.9$ & $58 \pm 10$ & $83 \pm 6$ & $35 \pm 8$ \\
\hline & M5 & $14.8 \pm 4.7$ & $14.9 \pm 5.9$ & $56 \pm 6$ & $86 \pm 6$ & $37 \pm 6$ \\
\hline & M6 & $14.4 \pm 5.7$ & $14.7 \pm 5.6$ & $58 \pm 8$ & $85 \pm 5$ & $35 \pm 9$ \\
\hline \multirow{6}{*}{ GII } & M1 & $3.6 \pm 3.8$ & $19.8 \pm 2.2$ & $44 \pm 9$ & $79 \pm 11$ & $29 \pm 4$ \\
\hline & M2 & $2.8 \pm 2.3$ & $20.0 \pm 1.9$ & $42 \pm 9$ & $77 \pm 8$ & $31 \pm 5$ \\
\hline & M3 & $4.0 \pm 4.4$ & $19.9 \pm 1.9$ & $44 \pm 11$ & $79 \pm 8$ & $29 \pm 3$ \\
\hline & M4 & $2.9 \pm 1.8$ & $19.1 \pm 1.7$ & $46 \pm 11$ & $78 \pm 8$ & $30 \pm 3$ \\
\hline & M5 & $3.0 \pm 2.4$ & $20.2 * \pm 1.7$ & $49 \pm 13$ & $80 \pm 12$ & $32 \pm 3$ \\
\hline & M6 & $3.2 \pm 2.5$ & $19.7 \pm 1.9$ & $48 \pm 11$ & $76 \pm 10$ & $31 \pm 5$ \\
\hline
\end{tabular}

$\mathrm{S}$ - right-to-left Shunt; $\mathrm{P}_{\mathrm{wV}}$ - water vapor pressure; $\mathrm{P}_{\nabla} \mathrm{O}_{2}$ - mixed venous blood oxygen partial pressure; $\mathrm{S}_{\nabla} \mathrm{O}_{2}-$ mixed venous blood oxygen saturation; $\mathrm{P}_{\mathrm{a}} \mathrm{CO}_{2}-$ arterial carbon dioxide partial pressure; ${ }^{\&} \mathrm{p}<0.001$ and GI $>\mathrm{GII} ;{ }^{*} \mathrm{p}<0.05$ and GI $>$ GII; ${ }^{*} \mathrm{p}<0.05$ and GI $<$ GII; * $\mathrm{p}$ $<0.05$ versus $\mathrm{M} 1 ;{ }^{\mathfrak{}} 0.05<\mathrm{p}<0.10$ and $\mathrm{GI} \geq \mathrm{GII}$. 


\section{Discussion}

The heart rate was higher than normal for the species in both groups although a decrease occurred as time passed by. In GI, with non-rebreathing system, the rise was easily observed. The use of sevoflurane did not change or raise the heart rate even slightly either. Nevertheless, the combination of thiopental with no pre-medication drugs may have been responsible for triggering that increase. ${ }^{14}$ Ebert et al. ${ }^{15}$ observed $30 \%-40 \%$ rise in heart rate of dogs by using 1.2-2.0 values of minimum sevoflurane alveoli concentration. Mean arterial pressure did not show any change whatsoever, what indeed was expected to be so since the used drugs (thiopental and sevoflurane) cause cardiac output and systemic vascular resistance to slightly change. Sevoflurane can also maintain the cardiac output. ${ }^{15}$ In the present study it was observed that right-to-left shunt was higher on the group that was treated with a non-rebreathing system with $\mathrm{F}_{\mathrm{I}} \mathrm{O}_{2}=0.9$ (GI). Not only the cardiac output but also pulmonary perfusion may be affected by anesthesia and by mechanical ventilation, influencing blood oxygenation. In case of affecting the ventilation, and the ventilation becomes lower than the perfusion, it may be considered as an alteration in the ventilation/perfusion ratio - hypoventilated lung areas which have this low ratio. Other areas not ventilated but irrigated characterize the shunt. ${ }^{16}$ An adjustment between the ventilation and blood flow is required to provide an efficient gas interchange in multiple lung areas. The ratio must be equal to one unit, i.e., for each unit of alveoli ventilation there must be one unit of pulmonary flow. When regional perfusion exceeds ventilation, shunt happens causing the ratio to be lower than one unit. It can be considered in capillary and anatomic component. Capillary shunt is represented by blood flow which can suffer gas exchange with ventilate alveoli, but, for some reason, those changes did not happen. It can be considered true capillary shunt and venous admixture. True capillary shunt exists when there is no ventilation, although the perfusion for the non-ventilated areas continues in a finite basis. In venous admixture (low ventilation/perfusion ratio or shunt effect) ventilation is greatly reduced, however presents in finite basis, when compared to perfusion. Even being the shunt composed of blood trespassing physically capillary lung bed, physiologically, this blood is not oxygenated. True capillary shunt is commonly associated to atelectasis. There is a relationship between $\mathrm{F}_{\mathrm{I}} \mathrm{O}_{2}$ and shunt formation. ${ }^{10}$ Authors observed that individuals with high $\mathrm{F}_{\mathrm{I}} \mathrm{O}_{2}$ (higher than 0.85) develop a higher pulmonary atelectasis grade when compared with lower $\mathrm{F}_{\mathrm{I}} \mathrm{O}_{2}$ individuals (up to 0.50). The same was observed by Rothen et al. ${ }^{2}$ - higher shunt incidence with $\mathrm{F}_{\mathrm{I}} \mathrm{O}_{2}=1.0$ when compared to 0.3 . The use of $100 \%$ oxygen at the end of anesthesia causes postoperative atelectasis while the association of a vital capacity maneuver (intubated patient and pulmonary ventilation with $40 \mathrm{cmH}_{2} \mathrm{O}$ pressure for 15 seconds) with a $\mathrm{F}_{\mathrm{I}} \mathrm{O}_{2}$ of 0.4 prevents atelectasis formation. ${ }^{17}$ Several authors correlate shunt and atelectasis ${ }^{5,11}$ and $\mathrm{P}_{\mathrm{a}} \mathrm{O}_{2}$ and atelectasis 8 ; hence, $\mathrm{P}_{\mathrm{a}} \mathrm{O}_{2}$ must be directly affected by atelectasia. According to Tusman et al. ${ }^{18}$, using strategic alveoli recruitment with $25-40 \mathrm{cmH}_{2} \mathrm{O}$ pressures for some period of time resulted in a $\mathrm{P} \mathrm{O}_{2}$ increase. Some other authors ${ }^{8}$ also observed that $75 \%$ in $\mathrm{P}_{\mathrm{a}} \mathrm{O}_{2}$ variation occurred by atelectasis and airway closing. Nitrogen is the gas responsible for keeping alveoli opened in regions with low ventilation/perfusion ratio. However, during high oxygen concentrations, nitrogen is removed from the alveoli causing them to collapse. This phenomenon was observed in individuals breathing an oxygen fraction higher than 0.6. ${ }^{19}$ In the present study, $\mathrm{GI} \mathrm{F}_{\mathrm{I}} \mathrm{O}_{2}$ was 0.9 explaining the higher shunt values found. Airway humidity is vital for the integrity of the respiratory epithelium. Physiologically, air (at $21^{\circ} \mathrm{C}$ and $50 \%$ of relative humidity) is heat up to $34^{\circ} \mathrm{C}$ and relative humidity is increased to $80-90 \%$ as it goes through the nose. When it reaches the carina inhaled air becomes $100 \%$ humidified and displays a temperature of $37^{\circ} \mathrm{C}$. During anesthesia, superior airways are replaced by a tracheal tube which leads cold and dry air straight to alveoli. Normal mucus sheath becomes dry and oozy leading to airway obstruction. Ciliary function decreases in early stages, inhibiting upward mucus normal movement to the mouth. Warmth is directly lost by the respiratory tract due to water vaporization. If the loss is intense it may even decrease body temperature. Artificial gases humidification will reduce the loss of body temperature seen after surgery procedures and hence decreasing the incidence of postoperative problems such as high oxygen consumption and blood vessels constriction. This process causes dehydration of superior airways resulting in total loss of cilia movement, leading to functional and structural changes, ${ }^{13}$ resulting in secretion retention, low bacterial clearance, atelectasis (and shunt as a result), and pneumonia. Airway lesion is directly proportional to duration of ventilation with dry gases and the period of time necessary to its recovery is inversely proportional to the ventilation duration. Superficial recovery, as new cilia grow, may take 2 to 3 days while the recovery of the thick mucosa takes 2 to 3 weeks. ${ }^{20}$ In order to avoid the dryness of alveoli, that leads to pulmonary unit collapse and so to shunt, its necessary that inhaled gases ${ }^{13}$ get some humidification. There are several ways to heat and humidify inhaled gases although the best and efficient way is to use carbon dioxide absorbents and gas rebreathing because the chemical reaction generates heat and moisture, simulating the normal function. ${ }^{12}$ A reference value used to evaluate alveoli ventilation and early detection of atelectasis formation is the arterial carbon dioxide partial pressure. ${ }^{20}$ Carbon dioxide is the final product of cellular metabolism and must be continuously excreted to avoid acidosis. Normal $\mathrm{pH}$ maintenance depends on two mechanisms to eliminate this gas - respiratory and renal (acute and chronic mechanism, respectively). For the occurrence of respiratory mechanism, it is necessary that carbon dioxide be transported through blood during all period of elimination. Its arterial pressure oscillates in gaps considered physiological, in humans, to $34-42 \mathrm{mmHg}$. This study was carried out during an acute situation in order to result in early atelectasis detection. Knowing that, even being the mechanical ventilation responsible for arterial carbon dioxide elimination changes it is believed that there was no misbalance in gas elimination as there was a close attention to dog's ventilation and a short period of time between anesthesia onset, mechanical ventilation establishment and data gathering. Normal mixed venous blood oxygen saturation values range from 0.68 to 0.77 . In this interval there is a normal balance between oxygen supply and demand, balance provided by intact regulation of vessels and normal distribution of peripheral blood flow. Values higher than 0.77 signals excess supply in relation to consumption and match commonly with syndromes 
in which there are vessels regulation disturbs like sepsis and cirrhosis. The high values are also seen in low oxygen consumption as in hypothermia, with neuromuscular blocking drugs use, and so in muscular paralysis, in sedation, in coma or in the sum of all or some of those factors and in hyperoxygenation and cardiac output rise. ${ }^{20}$ Animals from both groups had high oxygen saturation values for mixed venous blood and it is believed that low oxygen consumption, which may have occurred due to anesthesia and neuromuscular blocking, may explain this phenomenon. In GI with $\mathrm{F}_{\mathrm{I}} \mathrm{O}_{2}>0.9$ it was obtained values higher than in GII still as was expected.

\section{Conclusion}

The group with anesthesia in non-rebreathing system and with $\mathrm{F}_{\mathrm{I}} \mathrm{O}_{2}=0.9$ developed higher right-to-left pulmonary shunt when compared to the rebreathing $\mathrm{F}_{\mathrm{I}} \mathrm{O}_{2}=0.4$ system, which presented normal shunt values. Gases humidification granted by the rebreathing system was a factor that decreased pulmonary shunt occurrence by simulating the normal respiratory physiology in dogs as experimental models.

\section{References}

1. Strandberg A, Tokics L, Brismar B, Lundquist H, Hedenstierna G. Atelectasis during anaesthesia and in the postoperative period. Acta Anaesthesiol Scand. 1986; 30:154-8.

2. Rothen HU, Sporre B, Engberg G, Wegenius G, Reber A, Hedenstierna G. Prevention of atelectasis during general anaesthesia. Lancet. 1995; 345:1387-91.

3. Rusca M, Proietti S, Schnyder P, Frascarolo P, Hedenstierna G, Spahn DR, Magnusson L. Prevention of atelectasis formation during induction of general anesthesia. Anesth Analg. 2003; 97:1835-9.

4. Cote CJ, Goldstein EA, Cote MA, Hoaglin DC, Ryan JF. A single-blind study of pulse oximetry in children. Anesthesiology. 1988; 68:184-8.

5. Brismar B, Hedenstierna G, Lundquist H, Strandberg A, Svensson L, Tokics L. Pulmonary densities during anesthesia with muscular relaxation: a proposal of atelectasis. Anesthesiology. 1985; 62:422-8.

6. Gander S, Frascarolo P, Suter M, Spahn DR, Magnusson L. Positive end-expiratory pressure during induction of general anesthesia increases duration of nonhypoxic apnea in morbidly obese patients. Anesth Analg. 2005; 100:580-4.
7. Rothen HU, Sporre B, Engberg G, Wegenius G, Hedenstierna G. Re-expansion of atelectasis during general anaesthesia may have a prolonged effect. Acta Anaesthesiol Scand. 1995; 39:118-25.

8. Rothen HU, Sporre B, Engberg G, Wegenius G, Hogman M, Hedenstierna G. Airway closure, atelectasis and gas exchange during general anaesthesia. Br J Anaesth. 1998; 81: 681-6.

9. Tenling A, Hachenberg T, Tyden H, Wegenius G, Hedenstierna G. Atelectasis and gas exchange after cardiac surgery. Anesthesiology. 1998; 89: 371-8.

10. Lundh R, Hedenstierna G. Ventilation-perfusion relationships during halothane anaesthesia and mechanical ventilation. Effects of varying inspired oxygen concentration. Acta Anaesthesiol Scand. 1984; 28:191-8.

11. Edmark L, Kostova-Aherdan K, Enlund M, Hedenstierna G. Optimal oxygen concentration during induction of general anesthesia. Anesthesiology. 2003; 98:28-33.

12. Torres MLA, Carvalho JCA, Bello CN, Cremonesi E, Mathias RS. Sistemas respiratórios valvulares com absorção de gás carbônico: capacidade de aquecimento e umidificação dos gases inalados em três tipos de montagens utilizadas em aparelhos de anestesia no Brasil. Rev Bras Anestesiol. 1997; 47:89-100.

13. Bisinotto FMB, Braz JRC, Martins RHG. Umidificação dos gases inalados. Rev Bras Anestesiol. 1999; 49:349-59.

14. Manica JT e colaboradores. Anestesiologia: Princípios e Técnicas. 3ed. Porto Alegre : Artmed Editora; 2004.

15. Ebert TJ, Harkin CP, Muz M. Cardiovascular responses to sevoflurane: a review. Anesth Analg. 1995; 81:11-22.

16. Hedenstierna G. Pulmonary perfusion during anesthesia and mechanical ventilation. Minerva Anestesiol. 2005; 71:319-23.

17. Benoit Z, Wicky S, Fischer JF, Frascarolo P, Chapuis C, Spahn DR, Magnusson L. The effect of increased $\mathrm{F}_{\mathrm{I}} \mathrm{O}_{2}$ before tracheal extubation on postoperative atelectasis. Anesth Analg. 2002; 95:1777-81.

18. Tusman G, Bohm SH, Suarez-Sipmann F, Turchetto E. Alveolar recruitment improves ventilatory efficiency of the lungs during anesthesia. Can J Anaesth. 2004; 51: 723-27.

19. Nunn JF. Applied respiratory physiology. 2ed. London: Bulterworths; 1979.

20. Miller RD. Miller's anesthesia. 6ed. Philadelphia: Elsevier Churchill Livingstone; 2005.

\section{Correspondence:}

Yara Marcondes Machado Castiglia

Faculdade de Medicina de Botucatu, Depto. Anestesiologia

Rubião Jr, s/n

18618-970 Botucatu - SP Brazil

Fax:(55 14)3815-9015

yarac@,fmb.unesp.br
Conflict of interest: none Financial source: none

Received: July 05, 2006

Review: August 13, 2006 Accepted: September 18, 2006

\section{How to cite this article:}

Rosa AL, Mota PCA, Castiglia MM. Right-to-left shunt determination in dog lungs under inhalation anesthesia with rebreathing and non-rebreathing system. Acta Cir Bras. [serial on the Internet] 2006 Nov-Dec;21(6). Available from URL: http://www.scielo.br/acb. 